\title{
Prevention of tetanus during the First World War
}

\author{
Peter Cornelis Wever, ${ }^{1}$ Leo van Bergen ${ }^{2}$
}

1 Department of Medical Microbiology and Infection Control, Jeroen Bosch Hospital, 's-Hertogenbosch, The Netherlands

${ }^{2}$ Department of Medical Humanities (Metamedica), VU University Medical Centre, Amsterdam, The Netherlands

\section{Correspondence to}

Dr P C Wever, Jeroen Bosch Hospital, Department of Medical Microbiology and Infection Control, PO Box 90153, 's-Hertogenbosch, $5200 \mathrm{ME}$, The Netherlands; pcwever@hotmail.nl

Accepted 12 April 2012 Published Online First 29 April 2012

\section{ABSTRACT}

The emergence of tetanus in wounded soldiers during the first months of the First World War (WWI) resulted from combat on richly manured fields in Belgium and Northern France, the use of modern explosives that produced deep tissue wounds and the intimate contact between the soldier and the soil upon which he fought. In response, routine prophylactic injections with anti-tetanus serum were given to wounded soldiers removed from the firing line. Subsequently, a steep fall in the incidence of tetanus was observed on both sides of the conflict. Because of fatal serum anaphylaxis associated with administration of serum at a time when purification methods still needed to be improved, it must be presumed that tens to hundreds of men might have died as a result of the routine administration of anti-tetanus serum during WWI. Yet anti-tetanus serum undoubtedly prevented life threatening tetanus among several hundred thousands of wounded men, making it one of the most successful preventive interventions in wartime medicine. After the abrupt fall in tetanus incidence in 1914 due to introduction of anti-tetanus serum, the incidence of the disease tended to become even lower as the war went on. This was probably due to earlier and more thorough surgical treatment, consisting of opening, cleaning, excision and drainage of wounds as early as possible. In this overview, recent battlefield findings from the Meuse-Argonne offensive in 1918 are used to illustrate common practices employed in the prevention of tetanus during WWI.

In September 2010, several military and medical objects dating back to the First World War (WWI) were found by the first author in the forests surrounding Cunel, a small village in Northern France. The heights of Cunel were among the objectives of US troops in the decisive MeuseArgonne offensive, which began on 26 September 1918. Over the course of 47 days, fierce battle between allied American and French forces and German troops contributed to the Armistice of 11 November 1918. Involving 1.2 million US troops, the Meuse-Argonne battle is the largest frontline commitment in American military history. Because of the number of casualties among the often inexperienced American soldiers (over 26000 killed, over 95000 wounded), the Meuse-Argonne offensive is considered 'America's deadliest battle'. ${ }^{1}$

Among the recovered objects was an empty glass vial measuring about 2 inches in height and 1 inch in diameter. Inscribed on the glass vial are the French words 'SERUM ANTITETANIQUE' encircling the letters 'IP' (figure 1). The antiserum once contained within the vial was serum containing protective antibodies against the tetanus bacterium, obtained from animals such as horses immunised by injection [referred to as vaccination] with this particular microorganism. The letters 'IP' are an acronym for 'Institut Pasteur', the institute in Paris named after the Frenchman Louis Pasteur which was founded in 1887 and dedicates itself to this day to the prevention and treatment of infectious diseases. Near to the vial, a glass ampoule measuring about 3 inches in length and 3/8 inch in diameter containing a beige coloured crystallised powder was found. This ampoule was part of a socalled 'B\&B iodine swab' produced by Bauer and Black, a Chicago based manufacturer of medical appliances (figure 2). The ' $\mathrm{B} \& \mathrm{~B}$ iodine swab' consisted of a glass ampoule containing $1.5 \mathrm{ml}$ of iodine tincture with a woven case on one end, which served as a brush. Breaking of the ampoule at the brush end, between the fingers and thumb, released iodine tincture, which could be painted on the surface of a wound for disinfection. US Army medical corpsmen carried a so-called 'medical corpsman's belt' with 10 large pockets, of which, according to regulations, the second from the left contained two boxes with six iodine swabs each. ${ }^{2}$ A Canadian WWI-era soldier song illustrates that both recovered objects are illustrative of common practices employed in the prevention of tetanus and wound disinfection during WWI:

Sure a little bit of shrapnel fell from out the sky one day,

And it nestled in my shoulder in a quaint and loving way;

And when the M.O. [medical officer] saw it, oh, it looked so sweet and fair,

He said, "Suppose we leave it, for it looks so peaceful there!"

Then he painted it with iodine to keep the germs away;

He injected anti-tetanus that hurts me to this day I had visions of old Blighty [slang for Britain]thought the Base [Hospital] at least was mine But he marked me "Fit for Duty" and he sent me up the Line! $!^{3}$

\section{EMERGENCE OF TETANUS DURING WWI}

At the time of WWI, the Gram positive sporulating toxin producing anaerobic bacterium Clostridium tetani, the causative agent of tetanus, was known as Bacillus tetani. ${ }^{4}$ Concerning B. tetani, German Army nurse Henriette Riemann wrote "in the earth, which bears this bacillus, it is the smallest, most cruel and most malicious weapon of this war". 5 It is commonly found in the intestinal tract of horses and other animals so that soil of cultivated lands where manure has been used is often highly infectious. ${ }^{6}$ In 1888, Sir William Gowers provided the archetypical description of the disease. "Tetanus is a disease of the nervous system characterised by persistent tonic spasm, with violent brief exacerbations. The spasm almost always commences in the muscles of the neck and jaw, causing closure of 


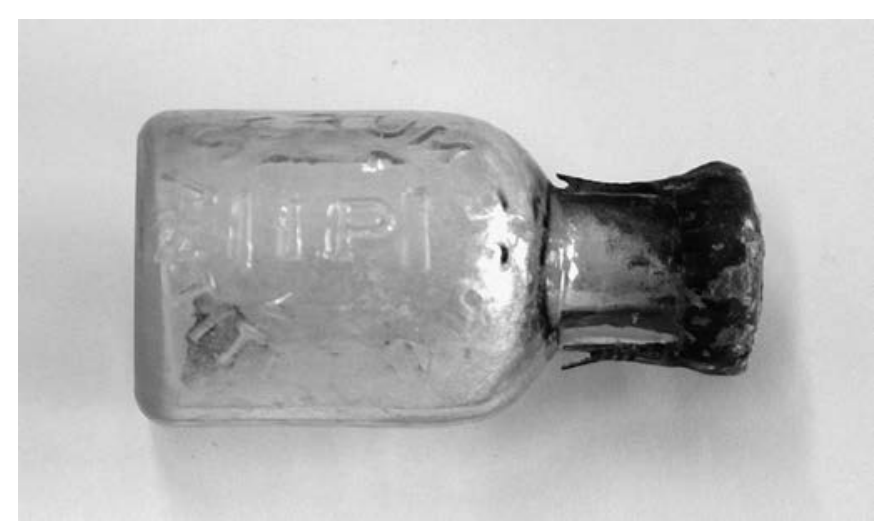

Figure 1 Glass vial with the inscription 'SERUM ANTITETANIQUE' encircling the letters 'IP' (acronym for 'Institut Pasteur') recovered in the vicinity of Cunel in the Meuse-Argonne region in Northern France (collection of the first author).

the jaws (trismus, lockjaw), and involves the muscles of the trunk more than those of the limbs. It is always acute in onset, and a very large proportion of those affected die." 7 During WWI, the War Office Committee for the Study of Tetanus in Britain acknowledged that the clinical picture of tetanus comprised general and local disease. General tetanus was defined as a disease "in which spasticity or rigidity occurs in muscles distant from the site of wound, trismus being the most common initial symptom in this form" while "the spasticity or rigidity is confined to the muscles in the neighbourhood of the wound" in local tetanus. Death was only observed in cases of general tetanus. A short incubation period, defined as the time between infliction of the wound and onset of symptoms, of up to 10 days was recognised as a risk factor for mortality. Fatal cases were, however, also observed in those with a longer incubation period. $^{8}$

Despite, for instance, a report in the Journal of the American Medical Association in 1913 on deaths from tetanus after firework injuries on Independence Day in the USA, ${ }^{9}$ the disease was considered uncommon in civil life in developed countries. ${ }^{10}$ However, immediately following the outbreak of WWI in 1914, an emergence of tetanus was observed among troops on both sides of the conflict. Between 1 August and 31 October, 1744 cases of tetanus were recorded among 27677 wounded soldiers in

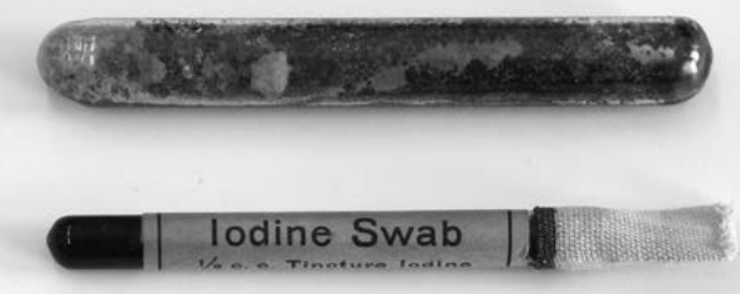

Figure 2 Above, a glass ampoule recovered in the vicinity of Cunel in the Meuse-Argonne region in Northern France containing $1.5 \mathrm{ml}$ of crystallised iodine tincture and part of a so-called 'B\&B iodine swab' carried by US Army medical corpsmen. Below, a complete $0.5 \mathrm{ml}$ 'B\&B iodine swab' with a woven case on one end, which served as a brush on breaking of the ampoule between the thumb and fingers (collection of the first author).
German military hospitals of the 15 th Army Corps. ${ }^{11}$ Reported mortality rates among German wounded who contracted tetanus in 1914 on the Western Front ranged from over $75 \%$ to $100 \% .{ }^{12}$ Likewise, numerous tetanus cases were observed in the first year of the war among injured British soldiers overseas as well as in home military hospitals with reported mortality rates of $78.2 \%$ and $57.7 \%$, respectively. ${ }^{13}$ Among factors contributing to the emergence of tetanus during the first months of WWI was the use of modern explosives. These produced deep tissue wounds in which dirt, originating from the richly manured soil on the fields of Belgium and Northern France, ${ }^{14}$ was driven inwards either directly or carried by penetrating objects. ${ }^{15}$ The extent to which the soil was infested is illustrated by the fact that even in peacetime it was common practice in the valley of the Aisne in Northern France, which the British Expeditionary Force reached in September 1914, to prophylactically inoculate farm horses with anti-tetanus serum. ${ }^{16}$ Furthermore, the contact between the soldier and the soil upon which he fought had never been more intimate than it was in the trenches and 'no man's lands' of WWI. Men were literally "covered from head to foot with clay and earth and mud" and "this mud [was] largely manurial in origin" ${ }^{11} 14$ In his biography on the life of 1945 Nobel Prize winner in Physiology or Medicine Alexander Fleming, who was a Royal Army Medical Corps officer during WWI stationed in Boulogne-sur-Mer, France, André Maurois wrote about "the terrible effects of explosives more powerful than those used in any previous war, and the infections set up in open wounds by earth and scraps of clothing", while "in the terrible butchery of 1914, by the time the injured reached hospital, their wounds were already crawling with microbes. Any poor wretch who happened to have fallen in a field or on a road was bound to have picked up any number of deadly germs". ${ }^{15}$ Yet, rarer causes of tetanus were also reported, such as a fatal case in which tetanus occurred in a soldier after receiving an intramuscular injection of quinine because of malaria contracted in Macedonia. Inoculation of a saline emulsion of the muscle from the site of the quinine injection subsequently induced tetanus in a guinea pig. ${ }^{17}$ Numerous fatal tetanus cases were also reported among soldiers with so-called 'trench foot'. ${ }^{18}$ This condition was one of the greatest plagues to hit the trenches. It resulted from restricted vascular supply to the feet as a result of ill fitting footwear, exposure to damp or simply having to stand in icy water for hours. 'Trench foot' presented with numbness, burning sensations, cyanosis, erythrosis and swelling, potentially leading to necrosis, gangrene and amputation. ${ }^{19}$ It was acknowledged that this condition was unlike "an ordinary gunshot or shell wound" for which reason prophylactic measures against tetanus had not been provided in the described fatal cases. $^{18}$

\section{ANTI-TETANUS SERUM}

In 1889, the Japanese bacteriologist Shibasaburo Kitasato was the first person to succeed in securing a pure culture of $B$. tetani and proving that it was the causative agent of the disease. ${ }^{4}$ In 1890, Kitasato and the German military doctor Emil von Behring, while working in Robert Koch's Hygiene Institute at the University of Berlin, published their landmark article 'On the mechanism of immunity to diphtheria and tetanus in animals' in the German Medical Weekly. ${ }^{20}$ This article described "experiments which show that the immunity to tetanus of experimental animals resides in the ability of the blood to render harmless the toxic products of the tetanus bacillus," while "this property is so stable that it remains effective even in the body of other animals, so that it is possible, through blood or serum 
transformations, to achieve an outstanding therapeutic effect". This work has been regarded as marking the birth of the medical discipline now known as serology or immunology. Yet it was for the subsequent introduction of diphtheria antitoxin treatment in humans that von Behring alone received the first Nobel Prize in Physiology or Medicine in 1901. At that time, diphtheria, unlike tetanus, was far more visible as a public health problem. Ironically, it was only during WWI that the merits of tetanus antitoxin treatment-and, therefore, Kitasato's tetanus antitoxin theory-were fully recognised. ${ }^{21}$

Britain declared war on Germany on 4 August 1914. Subsequently, the bulk of the British Expeditionary Force crossed over to France on the night of 12 August to enter into Belgium on 18 August. On 8 September, Lord Kitchener, Secretary of State for War, had already telegraphed the Director of Medical Services of the British Expeditionary Force, enquiring "as to whether anti-tetanus inoculations are being practised for wounded". However, it was not until the middle of October 1914 that the practice of prophylactic inoculation with anti-tetanus serum was introduced on a complete scale, which was followed by a steep fall in the incidence of tetanus in November (figure 3). ${ }^{16}$

The German response to the emergence of tetanus paralleled the British response. On 5 September 1914, Otto von Schjerning, Chief of Field Sanitary Services, urged the Prussian War Ministry to increase the output of anti-tetanus serum and to dispatch stockpiled serum to the front lines. A decree of 4 October

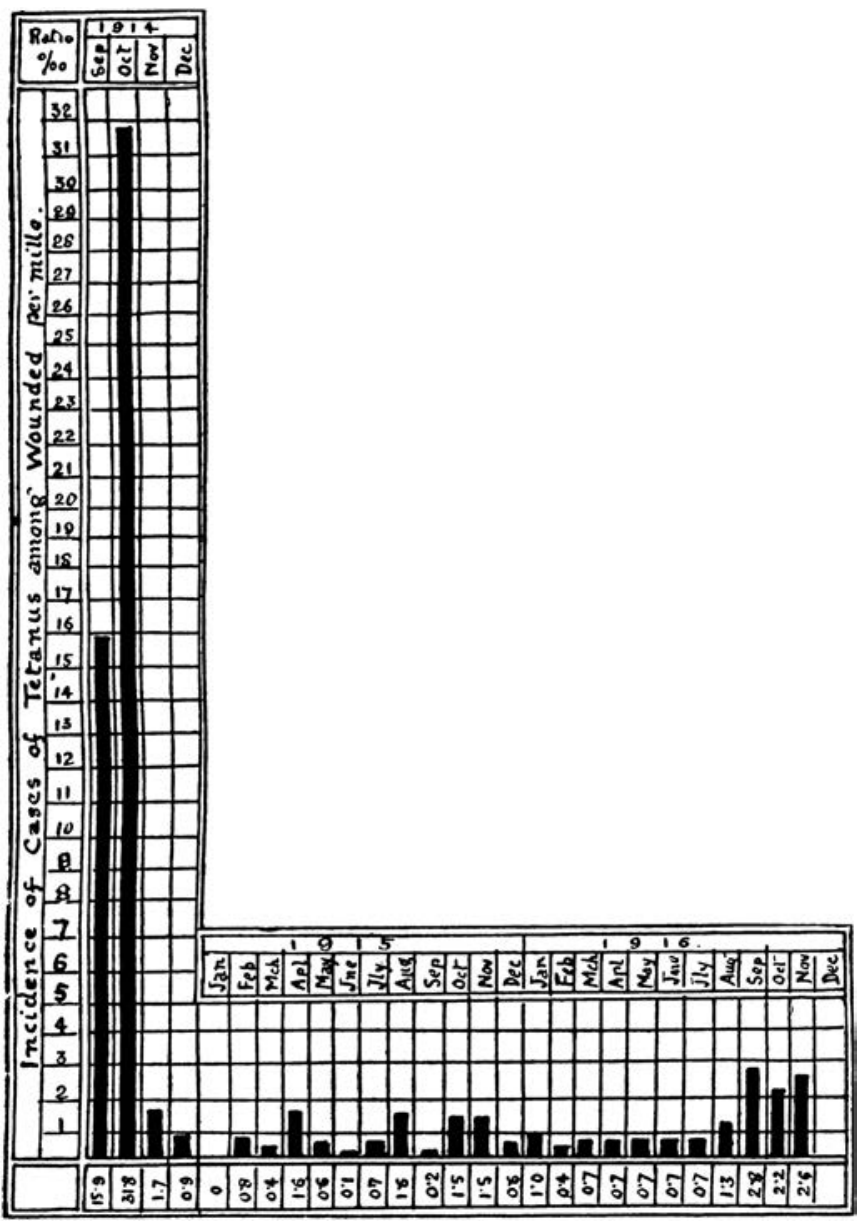

Figure 3 Incidence of tetanus per thousand wounded soldiers in British home military hospitals between September 1914 and November 1916 (graph reprinted from Bruce, ${ }^{16}$ with permission of the BMJ Group). recommended the preventive injection of anti-tetanus serum in all cases with larger wounds when dirt or horse manure was visible in or close to the wound. Soldiers with extensive wounds and those in which pieces of cloth or other foreign bodies were lodged were also to receive prophylactic anti-tetanus serum (figure 4). The State War Ministry rapidly adopted the recommendations. Production of anti-tetanus serum was increased substantially and shortfalls were compensated for by importing serum from neutral countries, at that time especially the USA. Soon, the beneficial effects of tetanus prophylaxis became evident. The doctor in chief from a fortress hospital in France reported that from 15 October onwards, when each wounded soldier was injected with anti-tetanus serum, no cases of tetanus had been seen among 1195 soldiers admitted, while 27 cases were observed among 998 soldiers admitted before that date. ${ }^{12}$

On 11 November 1916, the War Office Committee for the Study of Tetanus issued a (revised) memorandum in the British Medical Journal on the prophylaxis and treatment of tetanus, which was to a great extent based on experimental and clinical evidence. It was urged that a primary subcutaneous injection of anti-tetanus serum consisting of 500 so-called 'USA units' in $3 \mathrm{ml}$ of horse serum was administered at a casualty clearing station or field ambulance as soon as the wounded soldier was removed from the firing line. Strong experimental evidence suggested, however, that the immunity conferred by the primary injection with anti-tetanus serum was largely lost in about 10 days [through degradation by the human body of foreign horse derived antibodies; for humans, active immunisation (vaccination) with heat inactivated tetanus toxoid providing longlasting protection became available only in the 1920s]. Therefore, it was recommended that a second injection of 500 units should be given in all cases of septic wounds after 7 days. In cases of prolonged septic wounds, third and fourth injections of 500 units of anti-tetanus serum at 7 day intervals were recommended. Furthermore, 500 units of anti-tetanus serum should be administered to all patients undergoing surgery at the site of wounds, even when healed, if the operation was performed at an interval $>7$ days from the last injection. This last recommendation resulted from the observation that tetanus cases had occurred following simple surgery on wounds, which

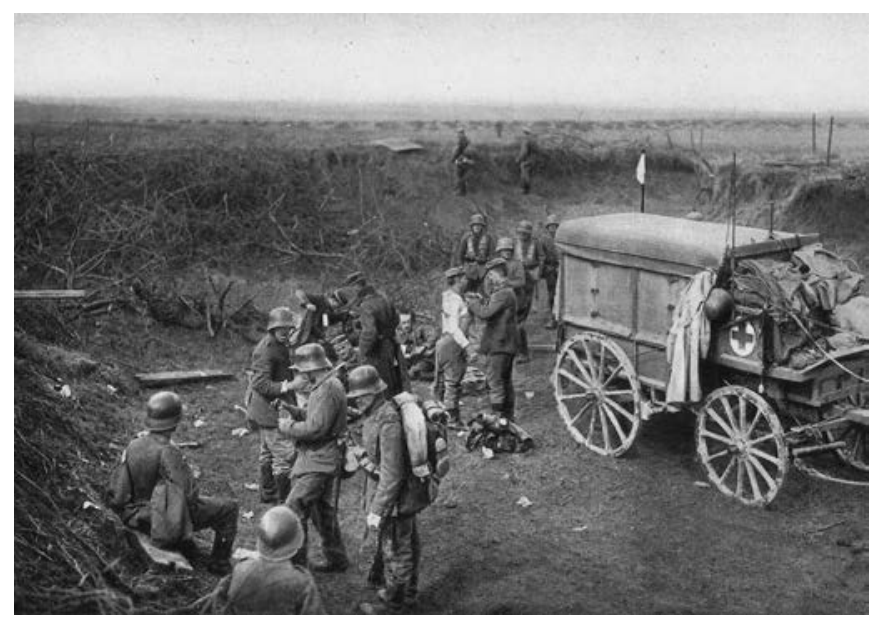

Figure 4 A First World War period photograph depicting a German first aid station with the caption "Wells in the landscape were often assembly points for the wounded [...] In particular, the "tetanus injections" for prevention of tetanus known to all German soldiers were administered here" (collection of the first author, photographer unknown). 
had healed several weeks before the operation. ${ }^{22}$ This is in line with a report that $B$. tetani was cultured from a shell fragment extracted from a forearm 6 months after the initial injury, although the patient did not show any clinical signs of infection. In this particular case, anti-tetanus serum was administered following receipt of the bacteriological findings. No symptoms of tetanus occurred subsequently. ${ }^{23}$

Vials of anti-tetanus serum for the British troops were supplied by the Vaccine Department of the Royal Army Medical College in London and usually contained 1500 units. Thus onethird of a vial was to be administered to a wounded soldier. ${ }^{22}$ In May 1918, it was reported that the equivalent of 10 million doses of 500 units of anti-tetanus serum had been dispatched by the Vaccine Department. ${ }^{24}$ It was stated that the danger of anaphylactic shock was negligible when doses of 500 units in $3 \mathrm{ml}$ of horse serum were given subcutaneously, regardless of the interval after the preceding injection. ${ }^{22}$ However, considering the enormous number of doses dispatched, episodes of anaphylactic shock must almost certainly have occurred even though the risk was considered negligible. In Germany, Emil von Behring seemed more aware of the risk of anaphylaxis, especially since the Prussian Ministry of the Interior had permitted 20 so-called 'AE units' (approximately 800 'USA units') ${ }^{4}$ to be applied, which was twice the normal amount, and required the injection of $10 \mathrm{ml}$ of serum. Concerned about the possibility of allergic reactions and serum sickness, von Behring urged that smaller doses of more concentrated serum should be injected and proceeded to produce high quality protein reduced serum at Behring Works. In October 1915, with the approval of Kaiser Wilhelm II, von Behring was awarded the Iron Cross 2nd Class as a sign of the gratitude of the fatherland for his discovery of anti-tetanus serum and his contributions to the German war effort. This was a highly unusual honour for a non-combatant. ${ }^{12}$

In 1952, the incidence of fatal serum anaphylaxis after administration of serum was estimated as lying between 1 in 50000 and 1 in $200000 .^{25}$ It must, therefore, be presumed that during WWI, tens to hundreds of men on both sides of the conflict might have died as a result of routine administration of anti-tetanus serum. In 1963, the results of a controlled clinical trial were published in which side effects of injection of antitetanus serum were recorded. Patients with a history of allergy or previous injection of serum were excluded. All eligible patients received a test dose of anti-tetanus serum and patients with subsequent symptoms suggestive of anaphylaxis were also excluded. The reactions to anti-tetanus serum consisted of local erythema and irritation at the injection site and generalised urticaria accompanied by systemic symptoms such as malaise, facial oedema, respiratory symptoms and joint pains in $5 \%$ and $8 \%$ of included patients, respectively. More than $75 \%$ of patients with a general reaction to anti-tetanus serum were confined to bed for at least part of their illness. ${ }^{26}$ This clinical trial, however, was performed at a time when methods of purifying serum had considerably improved, ${ }^{26}$ which suggests even more strongly that significant morbidity might have resulted from routine administration of anti-tetanus serum during WWI. Estimates are that over 20 million soldiers were seriously wounded between 1914 and 1918. Yet, because the distinction between the sick and wounded became blurred and wartime statistics are notoriously unreliable, there were probably millions more. ${ }^{19} 27$ Anti-tetanus serum undoubtedly prevented life threatening tetanus among several hundred thousands of them. ${ }^{21}$ Therefore, the mortality and morbidity associated with its prevention should be regarded as minor in comparison with the benefits.

\section{WOUND DISINFECTION AND SURGICAL PREVENTION}

In 1916, it was reported that antiseptics which might be of use in the prevention of tetanus included the group of oxidising antiseptics such as hydrogen peroxide, potassium permanganate, chlorine water and iodine solution, as these were unfavourable to anaerobic growth of $B$. tetani and had the power of rendering tetanus toxin non-toxic. ${ }^{22}$ During WWI, US Army medical corpsmen carried two boxes with six iodine swabs for disinfection of wounds. ${ }^{2}$ Likewise, the so-called 'first field dressing', which was issued to British soldiers, contained gauze, safety pins and initially also a small ampoule of iodine tincture for the primary disinfection of a wound. ${ }^{28}$

Since its discovery by the French chemist Bernard Courtois in 1811, iodine had been tested, with mixed results, as a therapeutic agent for reportedly "every conceivable pathological condition". The first specific reference to the use of iodine tincture in wounds dates back to 1839 when British surgeon John Davies described its application to lacerated, contused and punctured wounds in his Textbook on Surgery. The earliest recorded account of iodine tincture being applied to wounds sustained on the battlefield goes back to 1862, the second year of the American Civil War. Thereafter, germicidal properties of iodine solution were described, for instance, by the French bacteriologist Casimir Davaine in 1873 and by 1905 Nobel Prize winner in Physiology or Medicine Robert Koch in 1881. Subsequently, iodine tincture became a requisite in all military field hospitals. At the beginning of WWI, most surgeons presumably felt confident that prompt application of iodine solution was sufficient for the primary disinfection of a moderate size wound. ${ }^{28}$

During WWI, however, battlefield conditions gave rise to grossly infected wounds against which no chemical antiseptic was of any avail, unless applied in an excessive strength, damaging to living tissues. ${ }^{28}$ In addition, modern explosives produced deep wounds, which were more than just simple cavities. ${ }^{15}$ Alexander Fleming, while stationed at the Research Laboratory attached to No 13 General Hospital in Boulogne-sur-Mer, ${ }^{29} 30$ attempted to imitate in vitro the diverticula, which exist in serious recently inflicted gunshot wounds through the creation of several small excrescences in a glass test tube. Subsequently, the test tube was filled with serum previously infected with faeces. After incubation, the test tube was emptied and subsequently washed and filled for varying time intervals with different common antiseptics. After emptying the disinfected test tube, it was filled with sterile serum and incubated for $24 \mathrm{~h}$. Under all conditions, this serum became infected indicating that bacteria had survived in the excrescences of the test tube despite application of antiseptics. Fleming concluded from this experiment that it was impossible to sterilise a wound with an antiseptic. ${ }^{15} 31$ Irrespective of Fleming's in vitro experiment, it was also stated that one just "need[s] to see a few wounds opened up at the clearing station to realise how impossible [...] first-aid disinfection of lacerated shell wounds [is]". ${ }^{32}$

Iodine tincture was found to have several side effects. The tincture itself could directly cause irritation to the skin. ${ }^{33}$ Moreover, the painting of a wound with iodine tincture and subsequent dressing with an antiseptic double cyanide of mercury gauze could cause blistering or serious burns as a result of chemical reactions. ${ }^{32}{ }^{34}$ Therefore, despite the well established fact that iodine possesses the power of rendering tetanus toxin non-toxic, ${ }^{35}$ iodine tincture was withdrawn from the 'first field dressing' and from all official wound treatment procedures in the British Army. ${ }^{28}$ An alcoholic solution of picric acid was considered more satisfactory than iodine tincture as it was less irritating to 


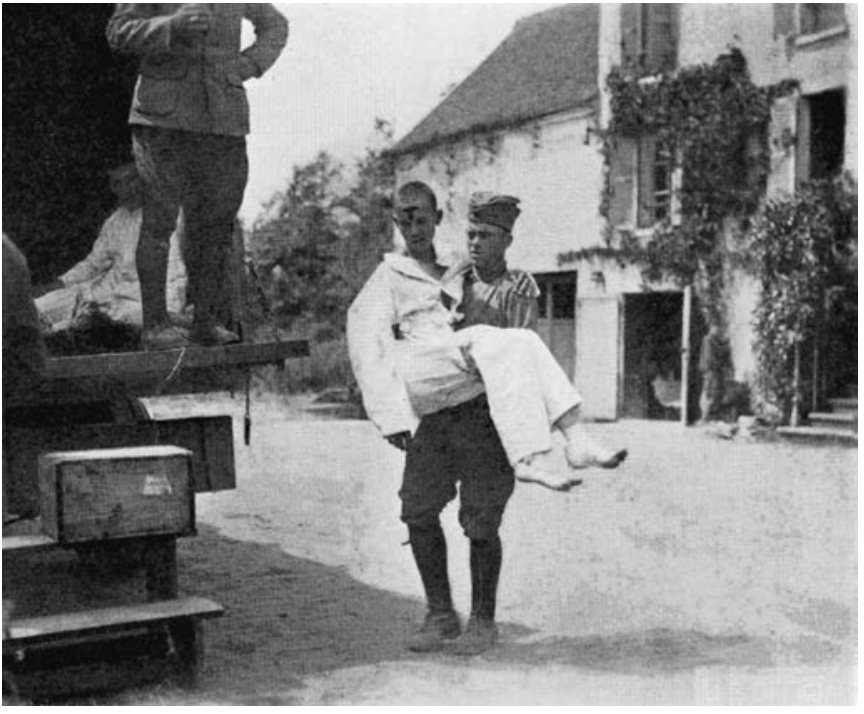

Figure 5 Evacuation of a wounded soldier from US Field Hospital No 15, near Montreuil, France, on 7 June 1918. On the forehead of the wounded soldier the letter ' $T$ ' is applied with iodine, indicating that he received anti-tetanus serum (photo reprinted with permission from the US Army Medical Department, Office of Medical History).

the skin and at the same time more lasting in its effect. ${ }^{33}$ An unconventional use of iodine during WWI by US forces was its use in the marking of casualties. A wounded man who had received anti-tetanus serum or morphine was marked with iodine on the forehead with the letters ' $\mathrm{T}$ ' or ' $\mathrm{M}$ ', respectively (figure 5). ${ }^{36}$

After the abrupt fall in tetanus incidence in 1914 due to introduction of anti-tetanus serum, the incidence of the disease tended to become even lower as the war went on. It has been stated that this was probably due to earlier and more thorough surgical treatment. Complete and early excision of gunshot wounds was recognised as a potent factor in the prevention of tetanus. Surgical prevention of tetanus, therefore, consisted of the removal of all damaged tissues before microorganisms carried into the wound could multiply to a dangerous degree, which was probably within the first $12 \mathrm{~h}$ after infliction of the wound. It was even stated that, had it not been for the sudden cessation of the war, probably "tetanus would have become extinct in the British Army as a war disease". 37 In 1917, the Medical War Manual No 1. Sanitation for Medical Officers was published for use by the US Army Medical Corps. This booklet was "created to supply in a compact form that can be conveniently carried in the pocket of a uniform, such data as may be useful to medical officers as a guide for sanitary work". Concerning the prevention of tetanus, the booklet advised, besides specific administration of anti-tetanus serum, general surgical measures comprising that "wounds should be freely opened, thoroughly cleaned and properly drained at the earliest possible moment". 6

\section{CONCLUSION}

Preventive measures employed in response to the emergence of tetanus in wounded soldiers during the first months of WWI resulted in a steep fall in the incidence of the disease on both sides of the conflict. Undoubtedly, anti-tetanus serum prevented life threatening tetanus among several hundred thousands of wounded men, making it one of the most successful preventive interventions in wartime medicine.
Acknowledgements The authors thank Emiel van den Bor, Maarten Otte and Jean-Paul de Vries for sharing their knowledge on WWI and the Meuse-Argonne offensive. The authors are grateful to Noret Gerbrands for librarian support, Yvonne Lemmens for assistance with the figures and Bob Rivett for linguistic suggestions.

Contributors PCW performed the literature search and wrote the historical review under the supervision of LvB.

Competing interests None.

Provenance and peer review Not commissioned; externally peer reviewed.

\section{REFERENCES}

1. Ferrel RH. America's Deadliest Battle. Meuse-Argonne, 1918. Lawrence, KS: University Press of Kansas, 2007:xi.

2. Ireland MW, Wolfe EP. The Medical Department of the United States Army in the World War. Volume III. Finance and Supply. Washington, DC: U.S. Government Printing Office, 1928:242.

3. Noyes FW. Stretcher-bearers ... at the Double! Toronto: The Hunter-Rose Company, 1937:199.

4. MacConkey A. Tetanus: its prevention and treatment by means of antitetanic serum. BMJ 1914;2806:609-14.

5. Riemann H. Schwester der Vierten Armee. Ein Kriegstagebuch. Berlin: Karl Vogels Verlag, 1930:101.

6. Vedder EB. Medical War Manual No. 1. Sanitation for Medical Officers. Philadelphia, PA: Lea and Febiger, 1917:180-1.

7. Gowers WR. A Manual of Diseases of the Nervous System. Philadelphia, PA: P. Blakiston's Son and Co., 1888:1027-49.

8. Anon. Tetanus in home military hospitals. BMJ 1917;2959:369-70.

9. Sharrard WJW. Wound management and the prevention of tetanus. Ir J Med Sci 1966;41:183-7.

10. Anon. The prevention of tetanus. Lancet 1920;196:508-9.

11. Pribram BO. Klinische und therapeutische Erfahrungen über den Tetanus. Berl Klin Woch 1915:52:865-9.

12. Linton DS. Emil von Behring. Infectious Disease, Immunology, Serum Therapy Philadelphia, PA: American Philosophical Society, 2005:357-62.

13. Bruce D. Analysis of cases of tetanus treated in home military hospitals from August, 1914, to August 1915. BMJ 1915;2860:593-6.

14. Moynihan B. An address on the treatment of gunshot wounds. BMJ 1916:2879:333-7.

15. Maurois A. The Life of Sir Alexander Fleming. Discoverer of Penicillin. New York, NY Dutton, 1959:83-97.

16. Bruce D. Note on the incidence of tetanus among wounded soldiers. BMJ 1917;2926:118-19.

17. Anon. Tetanus following intramuscular injection of quinine. BMJ 1918;2991:492

18. Bruce D. The importance of the early prophylactic injection of antitetanic serum in "trench foot." BMJ 1917;2924:48.

19. van Bergen L. Before My Helpless Sight. Suffering, Dying and Military Medicine on the Western Front, 1914-1918. Farnham: Ashgate, 2009:104-108:145.

20. von Behring $\mathbf{E}$, Kitasato $S$. Über das Zustandekommen der Diphtherie-Immunität und der Tetanus-Immunität bei Tieren. Dtsch Med Wochenschr 1890;16:1113-14.

21. Kantha SS. A centennial review; the 1890 tetanus antitoxin paper of von Behring and Kitasato and the related developments. Keio J Med 1991:40:35-9.

22. Anon. The War Office Committee on the Study of Tetanus. Memorandum on tetanus. BMJ 1916;2915:647-9.

23. Pybus FC, Slade HJ, Laws PCW. A note on the variety and latency of organisms on missiles in the tissues. BMJ 1919;3042:481.

24. Anon. Vaccines prepared at the Vaccine Department, Royal Army Medical College BMJ 1918:2993:548.

25. Laurent LJM, Parish HJ. Serum reactions and serum sensitivity tests. BMJ 1952:4771:1294-7.

26. Cox CA, Knowelden J, Sharrard WJW. Tetanus prophylaxis. BMJ 1963;5369:1360-6

27. Winter J. Demography. In: Horn J, ed. A Companion to World War I. Chichester: Wiley-Blackwell, 2010:248-62.

28. Kelly FC. lodine in medicine and pharmacy since its discovery-1811-1961. Proc $R$ Soc Med 1961:54:831-6.

29. Fleming A. On the bacteriology of septic wounds. Lancet 1915;186:638-43

30. Fleming A. Twentieth-century changes in the treatment of septic infections. N Eng/ J Med 1953;248:1037-45.

31. Fleming A. The action of chemical and physiological antiseptics in a septic wound Br J Surg 1919;7:99-129.

32. Smith SM. A lecture on treatment of the wounded in aid posts and field ambulances given to the medical officers of an American Division. BMJ 1918;3006:127-9.

33. Walker KM. Factors in field ambulance work which help the work in casualty clearing stations. BMJ 1917;2953:146-7.

34. Carbery AD. The New Zealand Medical Service in the Great War 1914-1918. Auckland: Whitcombe and Tombs, 1924:25.

35. MacConkey AT, Zilva SS. lodine in tetanus. BMJ 1916;2881:411-13.

36. Pottle FA. Stretchers. The Story of A Hospital Unit on the Western Front. New Haven, CT: Yale University Press, 1929:105.

37. Anon. Tetanus in home military hospitals. BMJ 1919;3053:16-17 


\section{Prevention of tetanus during the First World} War

Peter Cornelis Wever and Leo van Bergen

Med Humanities 2012 38: 78-82 originally published online April 29, 2012

doi: $10.1136 /$ medhum-2011-010157

Updated information and services can be found at:

http://mh.bmj.com/content/38/2/78.full.html

These include:

References This article cites 26 articles

http://mh.bmj.com/content/38/2/78.full.html\#ref-list-1

Email alerting Receive free email alerts when new articles cite this article. Sign up in service the box at the top right corner of the online article.

Notes

To request permissions go to:

http://group.bmj.com/group/rights-licensing/permissions

To order reprints go to:

http://journals.bmj.com/cgi/reprintform

To subscribe to BMJ go to:

http://group.bmj.com/subscribe/ 